\title{
臨床
}

肥厚性硬膜炎を合併したウェゲナー肉芽腫症例

\begin{tabular}{|c|c|c|c|}
\hline 片田＼cjkstart彰博 & ·岸部 & 幹・野澤はやぶさ & - 上田 \\
\hline 田 & ·林 & 達哉・小林 吉史 & - 野中 \\
\hline 長野 & 原㴊 & 保明 & \\
\hline
\end{tabular}

\section{A Case Report of Wegener's Granulomatosis with Hypertrophic Pachymeningitis}

\author{
Akihiro Katada, Kan Kishibe, Hayabusa Nozawa, Seigo Ueda, \\ Masanobu Imada, Tatsuya Hayashi, Yoshifumi Kobayashi, \\ Satoshi Nonaka and Yasuaki Harabuchi \\ (Asahikawa Medical College) \\ Etsuji Nagano \\ (Toyooka Chuo Hospital)
}

We report a case of Wegener's granulomatosis with hypertrophic pachymeningitis. A 36-year-old man presented with bilateral hearing loss and middle ear effusion. CT and exploratory mastoidectomy findings showed a granulomatous lesion with inflammatory cell infiltration in the mastoid cavity. The laboratory result was positive for C-ANCA. On the basis of these findings, the patient was diagnosed as Wegener's granulomatosis. Middle ear symptoms and signs were reduced by treatment with prednisolone and cyclophosphamide. However, severe headache and diplopia developed. Ga-DTPA-enhanced magnetic resonance imaging (MRI) revealed thickening of the dura mater in the tentorium cerebelli caused by hypertrophic pachymeningitis. Further treatment with prednisolone and cyclophosphamide improved these symptoms. The thickening of the dura mater in the tentorium cerebelli showed a dramatic improvement in MRI at 5 months after starting treatment.

Key words : Wegener's granulomatosis, patchymeningitis, C-ANCA

\begin{abstract}
はじめに
ウェゲナー肉芽腫症は原因不明の壊死性肉芽腫性血管 炎をきたす全身性疾患であるが，頭蓋内に病変が波及す ることはまれである. 今回われわれは，耳漏，めまいな どの耳症状を初発症状とし, 経過中に肥厚性硬膜炎を呈 したウェゲナー肉芽腫症例を経験したので報告する.
\end{abstract}

\author{
症例 \\ 症例 : 36 歳, 男性. \\ 主訴: 両耳漏. \\ 現病歴：2000 年 2 月, 両側の耳漏と回転性のめまいを \\ 自覚し, 近医耳鼻咽喉科を受診した。両側混合性難聴と \\ 左向き水平回旋性混合眼振を認め, 急性中耳炎による内
}


耳炎が疑われ，クリンダマイシンとセフォペラゾン・ス ルバクタム配合剤の点滴とプレドニゾロン $30 \mathrm{mg}$ からの 漸減投与が行われた。めまいは改善したが，中耳腔の貯 留液が消失せず, 両側鼓膜チューブ留置術が施行された。 その後，パニペネム，クラリスロマイシンの投与が行わ れたが, 鼓膜チューブからの耳漏が止まらず 2000 年 3 月 28 日当科入院となった.

家族歴 : 特記すべきことなし。

既往歴 : 脂肪肝による肝機能障害.

初診時現症および検查所見：両側の鼓膜は肥厚し，鼓 膜チューブが留置されていた。両側とも漿液性の耳漏が 少量認められた。鼻腔, 口腔, 咽喉頭には異常所見を認 めなかった。頸部リンパ節は触知しなかった。純音聴力 検査では，両側とも低音部の聴取レベルは $20 \sim 30 \mathrm{~dB}$ で 気骨導差があり，高音部では $40 \sim 50 \mathrm{~dB}$ で気骨導差のな い混合性難聴を呈した（図 1)。側頭骨 CT では両側乳突 蜂巣に陰影が認められたが，明らかな骨破壊像は認めら れなかった（図 2)。胸部 CT，および腹部 CT では，異 常所見を認めなかった。血液検査では，白血球数 11510 /

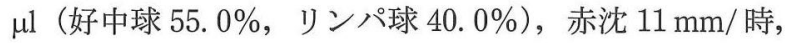
CRP $28.8 \mathrm{mg} / \mathrm{dl}$ と炎症反応が認められた。血清蛋白分画 はアルブミン $51.4 \% ， \alpha 1$ グロブリン $6.7 \% ， \alpha 2$ グロブ リン $8.0 \% ， \beta$ グロブリン $12.4 \% ， \gamma$ グロブリン $21.5 \%$ であった。C-ANCA は $300 \mathrm{EU}$ 以上と著明に上昇してい た。尿所見に異常なく，クレアチニンクリアランスも

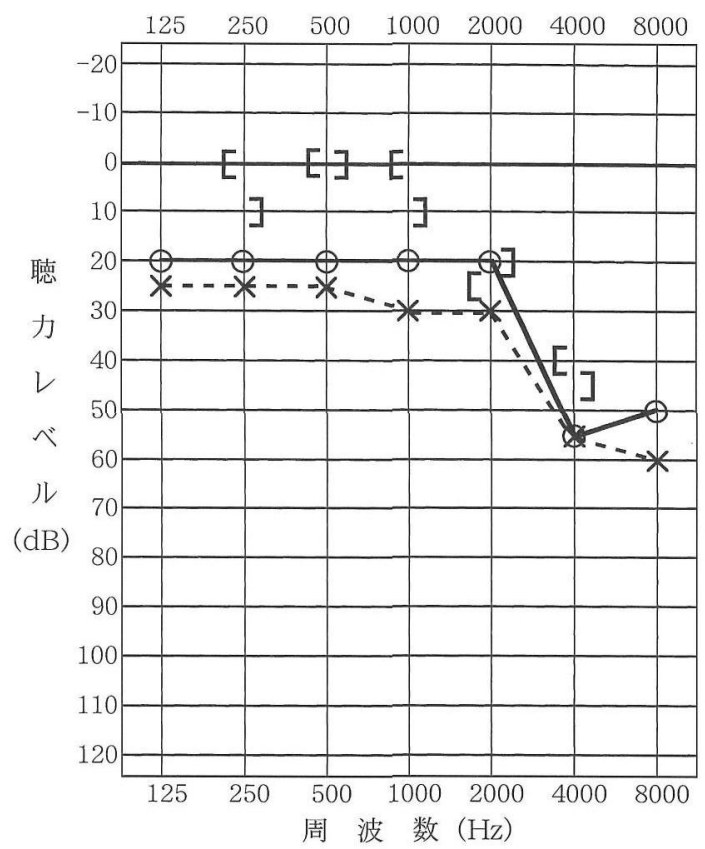

図 1 初診時純音聴力検查 高音障害型の両側混合性難聴を示している.

$106.3 \mathrm{ml} /$ 分と正常範囲であり腎機能障害は認めなかつ た.耳漏の細菌検査では，前医からの全経過を通じて明 らかな起因菌は同定されなかった。病理組織検查のため, 2000 年 4 月 14 日に右試験的乳突洞削開術を施行した。術 中所見では乳突洞は肉芽様組織で充満していた。病理所
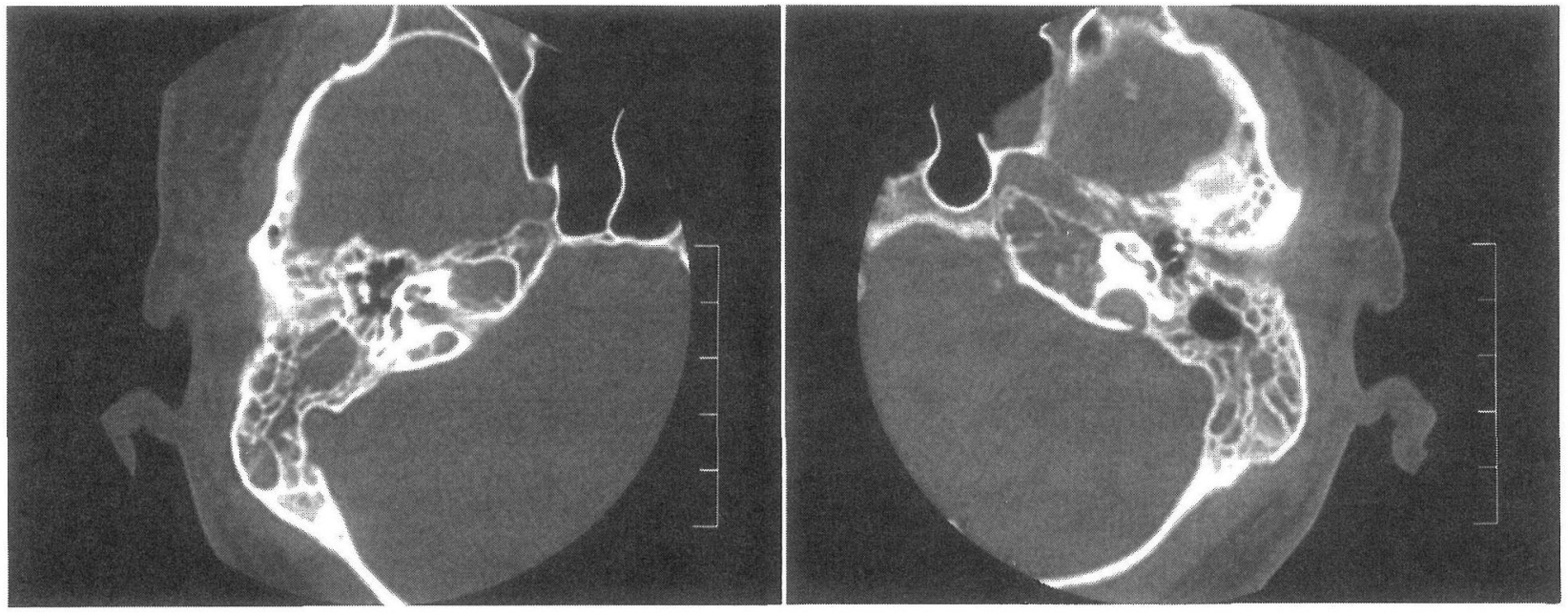

図 2 治療前の側頭骨 CT 所見（水平断） 両側の乳突蜂巣に陰影が認められるが，明らかな骨破壊像は認められない。 


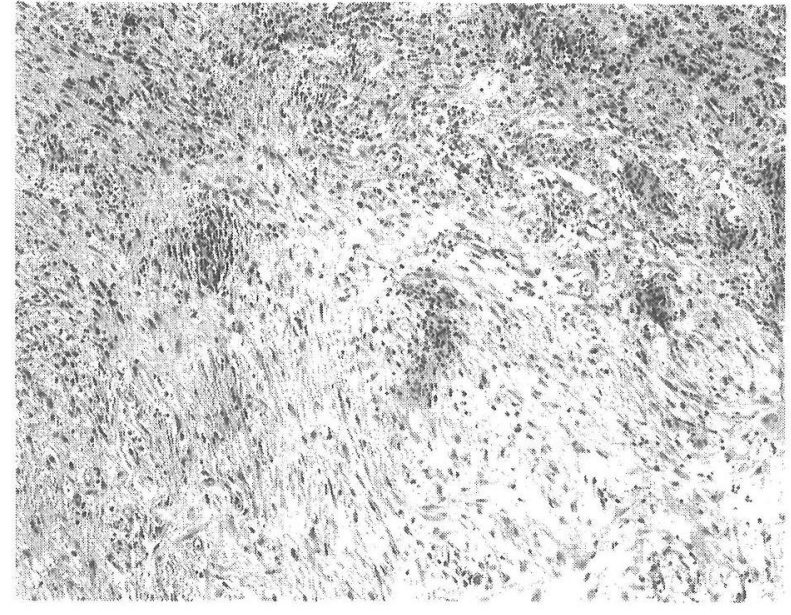

図 3 病理組織所見（HE 染色，400 倍）

炎症性細胞浸潤を伴ら肉芽組織であったが，壞死，血管 炎の所見は認められない.

見では，ウェダナー肉芽腫症に特幑的な壞死性血管炎の 所見は認められなかったが，好中球，リンパ球，形質細 胞等の慢性炎症細胞浸潤を背景した炎症性肉芽腫の像を 呈していた（図 3)。以上の経過および検查結果から，両 側中耳に限局したウェゲナー肉芽腫症と診断し治療を開 始した。

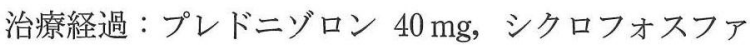
ミド $25 \mathrm{mg}$ の経口投与を開始し, 約 2 週間で耳漏が停止
した. CRP も $3.0 \mathrm{mg} / \mathrm{d} 1$ 以下となり正常化したため, 約 8 週間でプレドニン $10 \mathrm{mg}$ ，シクロフォスファミド $12.5 \mathrm{mg}$ まで渐減した。外来にて経過観察していたが, 2000 年 6 月中旬より強い頭痛と右眼球の内転障害による 複視が出現したため，当科汇再度入院となった。側頭骨 CT では乳突洞の軟部組織陰影は軽減していたが (図 4), 血液検查では，CRP $12.8 \mathrm{mg} / \mathrm{dl}$ と上昇しておうう，ウェグ ナー肉芽腫症の再燃が示唆された。頭部 MRI では，眼窩 内に特に異常は認められなかったが両側の小脳テントか ら左側頭部にかけての硬膜の肥厚が認められた（図 5)。 䯣液検查では特に異常所見を認めなかった。よって,ウェ ゲナー肉芽腫症に起因する神経炎および肥厚性硬膜炎と 診断し，プレドニゾロン $40 \mathrm{mg}$ ，シクロフォスファミド $75 \mathrm{mg}$ に増量した。その後 CRP，C-ANCA ともに改善を 認め, 右眼球内転障害は約 4 週間で, 頭痛は約 10 週間で 消失した。治療開始から 5 カ月後の頭部 MRI 所見では, 硬膜肥厚も改善していた（図 6)。現在治療後 1 年 6 力月 を経過しているが，プレドニゾロン $15 \mathrm{mg}$ ，シクロフォ スファミド $75 \mathrm{mg}$ で再燃なく経過良好である。

\section{考察}

ウェゲナー肉芽腫症の初発症状は鼻症状が最も多く, その頻度は $70 \sim 80 \%$ といわれている ${ }^{1)}$ 。一方, 本症例の ように耳症状が初発症状となる頻度は $10 〜 20 \%$ といわ れている11.われわれの経験した症例や諸家の報告2) 8)
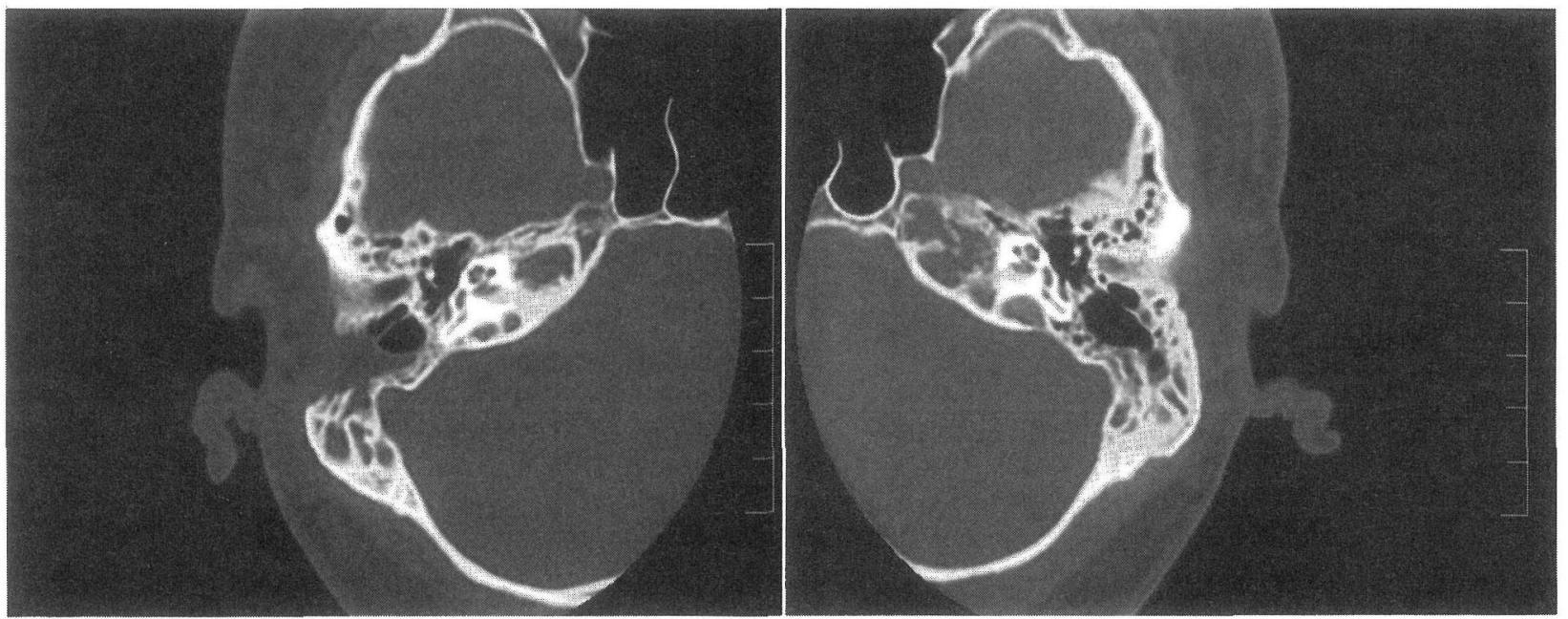

図 4 治療開始後の側頭骨 CT 所見（水平断）

右乳突蜂巣には試験的乳突洞削開術後の変化が認められる。両側とも乳突蜂巣の陰影が改善している。 

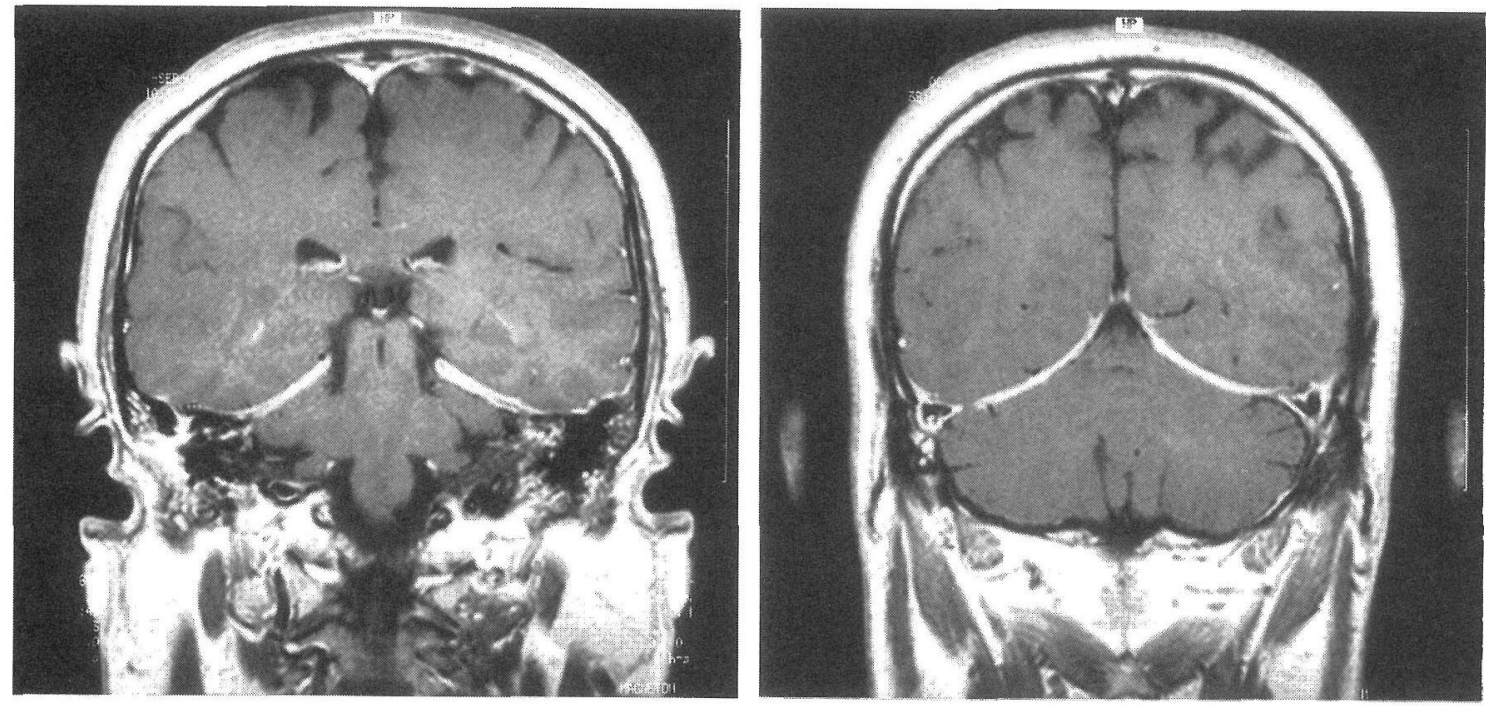

図 5 頭痛出現時の頭部 MRI（冠状断）

ガドリニウム造影 MRI で，両側小脳テントに硬膜の肥厚が認められる。
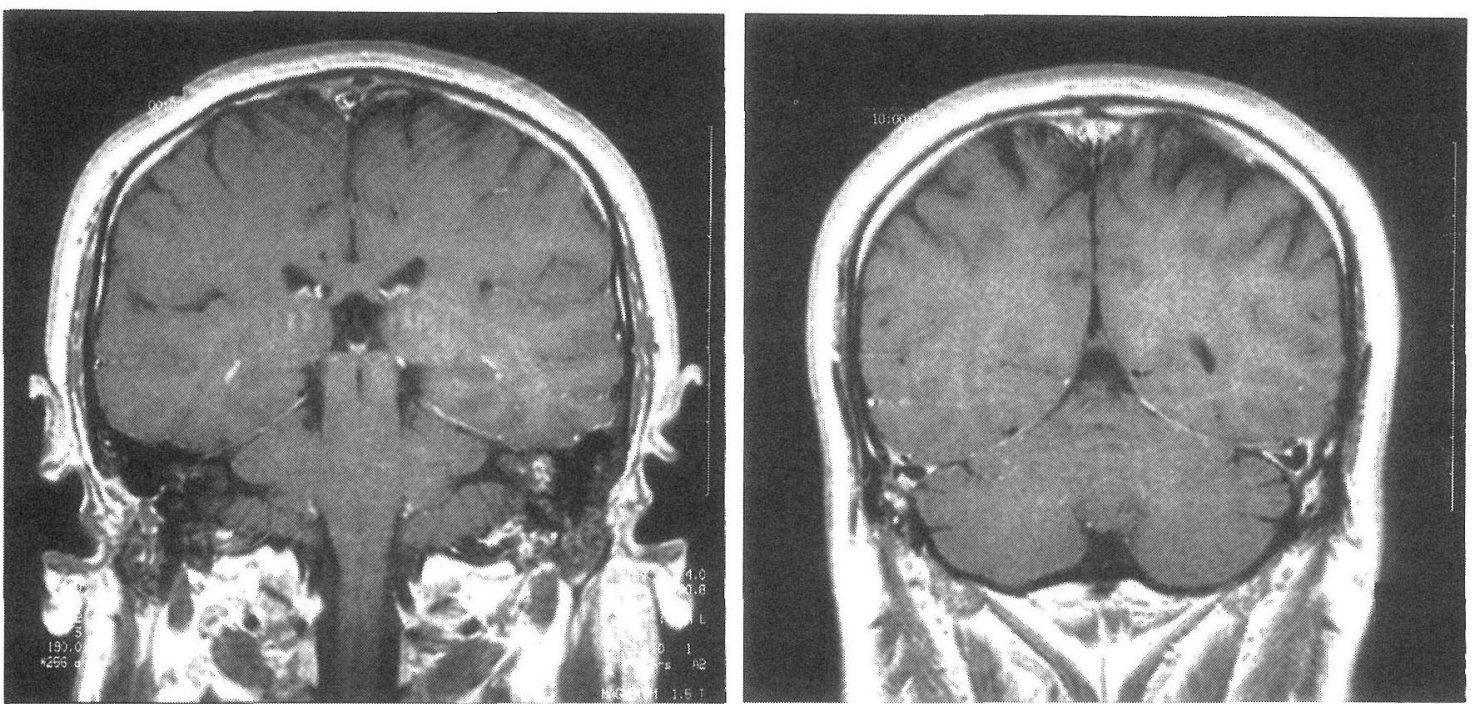

図 6 治療開始より 5カ月後の頭部 MRI（冠状断） 治療により硬膜の肥厚が消失している。

から，耳症状で発症するウェゲナ一肉芽腫症の早期発見 のポイントは以下の 7 項目に集約されると考えている。 すなわち，1）㳂出性中耳炎様症状方成人に発症する。 2) 鼓膜は肥厚し，時に肉芽腫性鼓膜炎を呈する．3）細菌検 查で原因菌が同定されない.4）抗生剤を使用しても反応 がみられない，5）鼓膜切開，鼓膜チューブ留置にようて も軽快せず難治性である。6）難聴は感音成分の低下もみ
られることもあり，混合性難聴を呈することがある。7） 側頭骨 CT にて骨破猿像はないが乳突洞や鼓室に軟部組 織院影が充満している。本症例の経過は，以上の所見を ほとんど满たしており，ウェゲナ一肉芽腫症に特異性の 高いマーカーである C-ANCA も高值であったため99，耳 症状で初発したウェゲナー肉芽腫症を疑った。

本症例では病理組織検査による診断の確定を行らた 
め，乳突洞の試験開洞を施行しているが，乳突洞より採 取した肉芽腫性病変にはウェグナー肉芽腫症に特徴的な 巨細胞を伴う壊死性肉芽腫性炎症や，フィブリノイド型 血管炎の存在は証明されなかった。しかしわれわれは, 病理組織学的な確定診断に至らなくとも臨床経過や検查 所見などからウェゲナー肉芽腫症が疑われる症例におい ては, 本疾患に有効とされるプレドニゾロンとシクロ フォスファミドの併用投与10)による治療を早期から積極 的に開始することが, 炎症を早急に沈静化させ, 重篤な 肺病変や腎病変を伴う全身型への進行を防ぐために重要 であると考えている2111)。本症例も厚生省特定疾患研究 班によるウェゲナー肉芽腫症の診断基準（1997 年） ${ }^{12)}$ か らウェダナー肉芽腫症疑い例と診断し, プレドニゾロン とシクロフォスファミドを併用投与することによって, 耳症状の軽快と CRP, C-ANCA の改善が認められた。

本症例は, 治療開始から約 2 力月後に頭痛と複視が出 現し，頭部 MRI 検查を施行したところ，硬膜の肥厚が認 められた. ウェゲナー肉芽腫症が神経症状を合併するこ とはまれではなく，その多くは血管炎に続発する単神経 炎であるといわれている ${ }^{13)}$. 脳神経が障害される頻度は $6 \sim 9 \%{ }^{13)}$ といわれており，ウェゲナー肉芽腫症に随伴 する脳神経症状としては視力低下, 複視, 顔面神経麻痺 の出現頻度が高い13) ことから脳神経の II, III, IV, VI, VII が 障害を受けやすいと考えられる。本症例に認められた内 直筋麻痺による左眼球内転障害は, 内直筋を支配する動 眼神経の神経炎によるものと考えられ，プレドニゾロン とシクロフォスファミドの増量により約 4 週間で消失し た.

一方, ウェゲナー肉芽腫症に随伴する髄膜病変は非常 にまれである。そこのほとんどは本症例と同様の肥厚性硬 膜炎であり,われわれが渉猟し得た限りでは 22 症例が報 告されている ${ }^{14)} \sim 31$. 本症例では, 髄膜の病理組織学的 検討が行われておらず断定はできないが，プレドニゾロ ンとシクロフォスファミドの増量により頑固な頭痛が消 失し, CRP, C-ANCA の低下とともに MRI 所見の改善を 認めたため, 臨床的にウェゲナー肉芽腫症による肥厚性 硬膜炎であると判断した。

ウェゲナー肉芽腫症による肥厚性硬膜炎の発症機序 は，鼻腔，咽頭，乳突洞などの肉芽腫性炎症や血管炎が 連続的に頭蓋内に波及する場合 ${ }^{14)}$ と，肉芽腫の遠隔性病 変として頭蓋内に病変が出現する場合 ${ }^{17)}$ 19) があると考 えられている. 本症例では, 明らかな活動性病変が両側
の乳突洞にしか認められなかったことから，乳突洞病変 の頭蓋内への波及を完全に否定はできない.しかし, 本 症例では初期治療により乳突洞病変は軽快しており, 肥 厚性硬膜炎出現時にも耳症状および乳突洞病変の増悪が 認められなかった。 よって, 本症例の髄膜病変は乳突洞 から連続して波及したものではなく, 肉芽腫の遠隔性病 変である可能性が高いと考えられた。

われわれが涉絾し得た髄膜病変を伴らウェゲナー肉芽 腫症 22 例中14) 31), てんかん, 片麻痻, 複視などの明ら かな中枢性病変の存在を疑うような症状が認められた症 例は 17 例であった. しかし残り 5 例では, 明らかな脳神 経症状がなく頭痛が認められるのみであった。 よって, ウェゲナー肉芽腫症の経過中に頑固な頭痛が認められた 場合には頭蓋内病変を疑って頭部MRI検查を積極的に施 行することが必要であると思われた。

髄膜病変を認めた 22 例のウェゲナー肉芽腫症で, 死亡

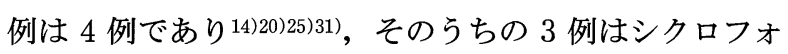
スファミドの副作用である間質性肺炎による死亡例で あった 20225331. したがって, 髄膜病変の存在はウェゲナー 肉芽腫症の予後を極端に悪化させるものではないと思わ れた。

ウェゲナー肉芽腫症の予後を改善するためには, 早期 診断, 早期治療によって重篤な全身型への移行を防ぐこ とが必須である．本症例のように，ウェゲナー肉芽腫症 は多彩な症状を呈する全身性疾患であることを念頭に置 き, 早期診断, 早期治療に務めることが重要であると考 えられた。

\section{まとめ}

1.耳症状で発症し,治療経過中に肥厚性硬膜炎を併発 したウェゲナー肉芽腫症例を報告した。

2. プレドニゾロンとシクロフォスファミドの投与に より, 臨床症状の改善と硬膜肥厚の軽減が認められた.

3. ウェゲナー肉芽腫症の経過中に, 頭痛や中枢神経症 状が認められた場合には頭蓋内病変を念頭に置き, MRI 検查を施行することが重要と考えられた.

この論文の要旨は第 63 回耳鼻咽喉科臨床学会（平成 13 年 6 月, 宜野湾市）で口演した。

\section{参考文献}

1）原㴊保明，形浦昭克：Wegener 肉芽腫症. CLIENT 21. 12 
鼻（夜陣紘治編）. $345 ～ 355$ 頁，中山書店，東京， 2000 .

2）石田芳也, 小林吉史, 坂東伸幸, 他 : 耳症状を呈したウェ ゲナー肉芽腫症の 2 例. 耳鼻臨床 $94: 685 \sim 691,2001$.

3）佐伯克哉, 村上信五, 白馬伸洋, 他：耳症状初発の限局型 ウェゲナー肉芽腫症 2 症例. 耳鼻臨床 $88: 325 〜 332,1995$.

4) 山口 朝, 原㴊保明, 浜本 誠, 他: 耳症状で初発したウェ ゲナー肉芽腫症例. 耳鼻臨床 $90: 531 \sim 536,1997$.

5) Illum $\mathrm{P}$ and Thorling $\mathrm{K}$ : Otological manifestations of Wegener's granulomatosis. Laryngoscope $92: 801 \sim 804,1982$.

6）泰地秀信, 猪狩武詔, 山田耕三, 他：早期に診断し得た Wegener 肉芽腫症の特徵. 耳鼻 $39: 42 \sim 48,1993$.

7) Bradley PJ : Wegener's granulomatosis of the ear. J Laryngol Otol $97: 623 \sim 626,1983$.

8) Dekker PJ : Wegener's granulomatosis; otological aspects. J Otolaryngol $22: 364 \sim 367,1993$.

9) Nolle B, Specks U, Ludemann J, et al. : Anticytoplasmic autoantibodies; their immunodiagnostic value in Wegener granulomatosis. Ann Intern Med 111: $28 \sim 40,1989$.

10）原㴊保明：ウェゲナー肉芽腫症のステロイド治療. 特集ス テロイドホルモンと耳鼻咽喉科. JOHNS $14: 1429 \sim 1443$, 1998.

11）原㴊保明, 形浦昭克：25. Wegener 肉芽腫症. 耳鼻咽喉科 診療 Q\&A. $1450 \sim 1453$ 頁, 六法出版社, 東京, 1997.

12）厚生省保健医療局疾病対策課（監）：ウェゲナー肉芽腫症. 難病の診断と治療指診 1.（財）難病医学研究財団企画委員 会. $250 \sim 256$ 頁，六法出版社，東京， 1997 .

13) Nishino H, Rubino FA, DeRemee RA, et al. : Neurological involvement in Wegener's granulomatosis; an analysis of 324 consecutive patients at the Mayo Clinic. Ann Neurol $33: 4 \sim$ 9, 1993.

14）江藤文夫, 島田幸彦, 遠藤久子, 他 : 著明な pachymeningitis を呈した Wegener 肉芽腫症の 1 剖検例. 臨床神経 $16: 326$ $\sim 332,1976$.

15) Oimomi M, Suehiro I, Mizuno N, et al. : Wegener's granulomatosis with intracerebral granuloma and mammary manifestation; report of a case. Arch Intern Med 140:853 854, 1980.

16) Scully RE, Mark EJ, McNeely WF, et al. : Case records of the Massachusetts General Hospital. (Case 12-1988). N Engl J Med $318: 760 \sim 768,1988$.

17) Tishler S, Williamson T, Mirra SS, et al. : Wegener granulomatosis with meningeal involvement. AJNR Am J Neuroradiol $14: 1248 \sim 1252,1993$.

18) Weinberger LM, Cohen ML, Remler BF, et al. : Intracranial Wegener's granulomatosis. Neurology 43:1831 1834, 1993.

19) Nishino H, Rubino FA and Parisi JE : The spectrum of neurologic involvement in Wegener's granulomatosis. Neurology
$43: 1334 \sim 1337,1993$.

20) Newman NJ, Slamovits TL, Friedland S, et al. : Neuro-ophthalmic manifestations of meningocerebral inflammation from the limited form of Wegener's granulomatosis. Am J Ophthalmol $120: 613 \sim 621,1995$.

21) Vaile JH, Owen ET, Rhodes HC, et al. : A granulomatous meningeal mass as the initial presentation of Wegener's granulomatosis. Aust N Z J Med $25: 369 \sim 370,1995$.

22) Jinnah HA, Dixon A, Brat DJ, et al. : Chronic meningitis with cranial neuropathies in Wegener's granulomatosis; case report and review of the literature. Arthritis Rheum $40: 573 \sim 577$, 1997.

23) Spranger M, Schwab S, Meinck HM, et al. : Meningeal involvement in Wegener's granulomatosis confirmed and monitored by positive circulating antineutrophil cytoplasm in cerebrospinal fluid. Neurology $48: 263 \sim 265,1997$.

24) Shiotani A, Mukobayashi C, Oohata $H$, et al. : Wegener's granulomatosis with dural involvement as the initial clinical manifestation. Intern Med $36: 514 \sim 518,1997$.

25) Tojo J, Nishimaki T, Ohyanagi $H$, et al. : An autopsy case of Wegener's granulomatosis with pachymeningitis. Intern Med $37: 711 \sim 715,1998$.

26) Scarrow AM, Segal R, Medsger TA, et al. : Communicating hydrocephalus secondary to diffuse meningeal spread of Wegener's granulomatosis; case report and literature review. Neurosurgery $43: 1470 \sim 1473,1998$.

27) Burrell HC and McConachie NS : Pachymeningitis in Wegener's granulomatosis. Australas Radiol 42 : $364 \sim 366,1998$.

28) Katrib A, Portek I, Corbett AJ, et al. : Meningeal involvement in Wegener's granulomatosis. J Rheumatol $25: 1009 \sim 1011$, 1998.

29) Nusbaum AO, Morgello S and Atlas SW : Pial involvement in Wegener's granulomatosis shown on MRI. Neuroradiology $41: 847 \sim 849,1999$.

30) Specks U, Moder KG and McDonald TJ : Meningeal involvement in Wegener granulomatosis. Mayo Clin Proc 75 : $856 \sim$ $859,2000$.

31) Nagashima T, Maguchi S, Terayama $Y$, et al. : P-ANCA-positive Wegener's granulomatosis presenting with hypertrophic pachymeningitis and multiple cranial neuropathies; case report and review of literature. Neuropathology $20: 23 \sim 30,2000$.

\author{
原稿受付：平成14年4月18日 \\ 原稿採択：平成14年6月19日 \\ 別刷請求先 : 片田彰博 \\ T078-8510 旭川市緑が丘東2条1-1-1 \\ 旭川医科大学耳鼻咽喉科・頭頸部外科学教室
}

